\title{
On the volatility and production mechanisms of newly formed nitrate and water soluble organic aerosol in Mexico City
}

\author{
C. J. Hennigan ${ }^{1}$, A. P. Sullivan ${ }^{2, *}$, C. I. Fountoukis ${ }^{3}$, A. Nenes ${ }^{2,3}$, A. Hecobian ${ }^{2}$, O. $\operatorname{Vargas}^{2}$, R. E. Peltier ${ }^{2, * * *}$, \\ A. T. Case Hanks ${ }^{2}$, L. G. Huey ${ }^{2}$, B. L. Lefer ${ }^{4}$, A. G. Russell ${ }^{1}$, and R. J. Weber ${ }^{2}$ \\ ${ }^{1}$ School of Civil and Environmental Engineering, Georgia Institute of Technology, Atlanta, GA, 30332-0340, USA \\ ${ }^{2}$ School of Earth and Atmospheric Sciences, Georgia Institute of Technology, Atlanta, GA, 30332-0340, USA \\ ${ }^{3}$ School of Chemical and Biomolecular Engineering, Georgia Institute of Technology, Atlanta, GA, 30332-0340, USA \\ ${ }^{4}$ Geosciences Department, University of Houston, Houston, TX, 77204-5007, USA \\ *now at: Colorado State University, Ft. Collins, Colorado, USA \\ ** now at: New York University, School of Medicine, USA
}

Received: 22 January 2008 - Published in Atmos. Chem. Phys. Discuss.: 5 March 2008

Revised: 27 May 2008 - Accepted: 17 June 2008 - Published: 16 July 2008

\begin{abstract}
Measurements of atmospheric gases and fine particle chemistry were made in the Mexico City Metropolitan Area (MCMA) at a site $\sim 30 \mathrm{~km}$ down wind of the city center. Ammonium nitrate $\left(\mathrm{NH}_{4} \mathrm{NO}_{3}\right)$ dominated the inorganic aerosol fraction and showed a distinct diurnal signature characterized by rapid morning production and a rapid mid-day concentration decrease. Between the hours of 08:00-12:45, particulate water-soluble organic carbon (WSOC) concentrations increased and decreased in a manner consistent with that of $\mathrm{NO}_{3}^{-}$, and the two were highly correlated $\left(R^{2}=0.88\right)$ during this time. A box model was used to analyze these behaviors and showed that, for both $\mathrm{NO}_{3}^{-}$and WSOC, the concentration increase was caused primarily $(\sim 75-85 \%)$ by secondary formation, with a smaller contribution $(\sim 15-25 \%)$ from the entrainment of air from the free troposphere. For $\mathrm{NO}_{3}^{-}$, a majority $(\sim 60 \%)$ of the midday concentration decrease was caused by dilution from boundary layer expansion, though a significant fraction $(\sim 40 \%)$ of the $\mathrm{NO}_{3}^{-}$ loss was due to particle evaporation. The WSOC concentration decrease was due largely to dilution $(\sim 75 \%)$, but volatilization did have a meaningful impact $(\sim 25 \%)$ on the decrease, as well. The results provide an estimate of ambient SOA evaporation losses and suggest that a significant fraction $(\sim 35 \%)$ of the fresh MCMA secondary organic aerosol (SOA) measured at the surface volatilized.
\end{abstract}

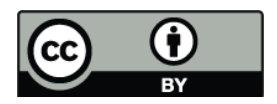

Correspondence to: C. J. Hennigan (chennigan@eas.gatech.edu)

\section{Introduction}

Secondary organic aerosol (SOA) is an important component of ambient particulate matter. It frequently comprises a large fraction of the total organic carbon aerosol (OC), often greater than $50 \%$ on a carbon mass basis (Kanakidou et al., 2005). Despite its high relative abundance and ubiquitous presence in the atmosphere, many characteristics of SOA are not well understood and require better characterization. These include chemical composition, relative contributions from anthropogenic and biogenic sources, and major formation mechanisms. These uncertainties inhibit the accurate modeling of SOA concentrations (e.g., Henze and Seinfeld, 2006).

One route for SOA formation is through gas-phase oxidation of volatile organic compounds (VOCs), which leads to less volatile products that may condense into the aerosol phase. Many of the condensed species are subsequently semi-volatile (i.e., they exist in both the gas and particle phase at typical atmospheric conditions) and contribute significantly to organic aerosol mass (Seinfeld and Pankow, 2003). Though this broad conceptual framework is generally accepted, the semi-volatile nature of SOA is not well constrained.

Multiple smog chamber experiments have analyzed SOA volatility, including Offenberg et al. (2006), Kalberer et al. (2004), and An et al. (2007). These studies have provided information about the volatility of specific secondary products (i.e., the volatility of SOA from $\alpha$-pinene/ozone and $\alpha$-pinene/ $\mathrm{NO}_{\mathrm{x}}$ experiments (An et al., 2007)). Thermal properties of ambient OA and SOA have been examined by

Published by Copernicus Publications on behalf of the European Geosciences Union. 

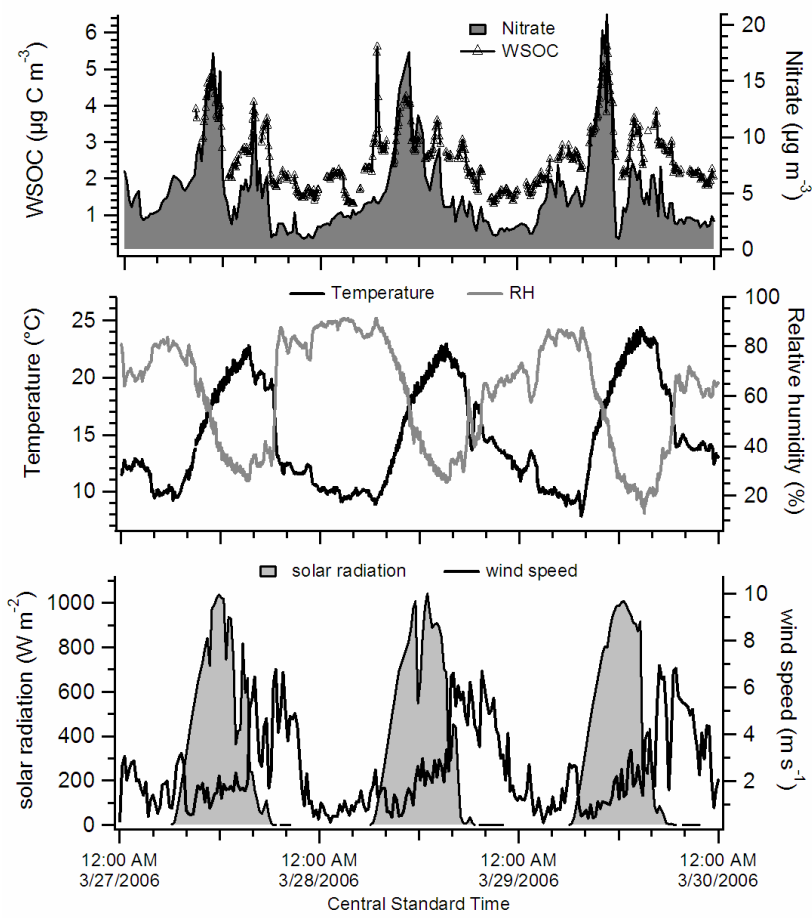

Fig. 1. Time series of measured $\mathrm{NO}_{3}^{-}$, WSOC, solar radiation, temperature, wind speed, and RH for 27-29 March. Concentrations of $\mathrm{NO}_{3}^{-}$and WSOC began to rise shortly after sunrise and model results (not shown) indicate that approximately $75 \%$ of the morning concentration increases were due to secondary aerosol formation.

analyzing the data (thermograms) from certain organic carbon analyzers (Yu et al., 2004), but the analyses were conducted at temperature heating profiles such that elucidating information on volatility in conditions relevant to the atmosphere was not possible.

Numerous studies focused on ambient aerosol have examined a semi-volatile fraction of the bulk organic aerosol using a sampling-based operational definition (e.g., Modey and Eatough, 2004). Semi-volatile organic matter (SVOM) is defined as those compounds which penetrate a quartz filter but are collected on a backup charcoal impregnated glass fiber filter in a gas-denuded sample stream. Using this operational definition, SVOM has been found to contribute significantly to $\mathrm{PM}_{2.5}$ mass in urban and rural locations in both winter and summer seasons (Wilson et al., 2006). Using the same operational definition, Eatough et al. (2003) coupled SVOM measurements with a source apportionment model to investigate sources and composition of aerosol in Utah. During a period in 2000 that was heavily influenced by biomass burning, they found that over 50\% of SOA was semi-volatile.

Though some studies have investigated the volatility of SOA, overall knowledge of ambient SOA volatility remains low. In this paper, the semi-volatile nature of SOA measured in the Mexico City Metropolitan Area (MCMA) is examined through simple box model analyses that involve a comparison with ammonium nitrate $\left(\mathrm{NH}_{4} \mathrm{NO}_{3}\right)$, a semivolatile species whose thermodynamic properties are well understood.

\section{Methods}

Measurements of aerosol and gas-phase species were made in March, 2006 as part of the Megacity Initiative: Local and Global Research Objectives (MILAGRO) field campaign. The study was focused on examining the chemical nature and processing of pollution outflow from the MCMA. Data reported here are from the ground-based measurement site, T1, located approximately $30 \mathrm{~km}$ downwind of the MCMA city center at the Universidad Tecnológica de Tecámac (lat 19.708 , lon -98.982 , elevation $2.2 \mathrm{~km}$ ). Measurements at T1 were performed from 7-31 March 2006; however the present analysis focuses only on the period of 27-29 March. The selected period was characterized by consistent diurnal behavior of $\mathrm{PM}_{2.5}$ mass and the highest daily maximum $\mathrm{NO}_{3}^{-}$concentrations (Fig. 1). It was also the period least impacted by biomass burning (Stone et al., 2008), which along with SOA is a source of fine particle WSOC (Sullivan et al., 2006). All concentrations are reported at ambient temperature and pressure.

Inlets for aerosol measurements were located approximately $10 \mathrm{~m}$ above the ground and were fitted with cyclones (URG, Chapel Hill, NC) to select particles with aerodynamic diameters less than $2.5 \mu \mathrm{m}\left(\mathrm{PM}_{2.5}\right)$. Water-soluble organic carbon (WSOC) aerosol was measured with a particle-intoliquid sampler (PILS) coupled to a total organic carbon analyzer (Sievers, Boulder, CO) (Sullivan et al., 2004). The PILS-WSOC method provides an approximate measurement of SOA mass (Sullivan et al., 2006; Kondo et al., 2007). Biomass burning is also a source for particulate WSOC and may account for some of the measured background WSOC observed in Mexico City. Stone et al. (2008) applied a chemical mass balance model to source apportion particle $\mathrm{OC}$ at $\mathrm{T} 1$ and attributed less than $10 \%$ of total OC to wood smoke for the 3/27-3/29 period. Additionally, the low correlation between a biomass burning tracer, acetonitrile (de Gouw et al., 2006), and WSOC $\left(R^{2}=0.18, n=467\right)$ during the $3 / 27-3 / 29$ period supports the findings that biomass burning contributions were low. Biomass burning contributions during other periods of the study were significantly higher. Aerosol inorganic ionic components were measured by a PILS coupled to dual ion chromatographs (IC) (Metrohm, Herisau, Switzerland) (Orsini et al., 2003) to quantify a suite of both cations and anions. Denuders were employed to remove potential interfering gases (e.g., $\mathrm{HNO}_{3}, \mathrm{NH}_{3}$ ) from the sample air stream immediately upstream of the PILS. Hydroxyl $(\mathrm{OH})$ and peroxy $\left(\mathrm{RO}_{2}\right)$ radical concentrations were measured with a chemical ionization mass spectrometer (CIMS) (Sjostedt et al., 2007). Measurements of nitric oxide (NO) and photolysis 
rates ( $\mathrm{J}$ values) were made with a chemiluminescence detector (Ryerson et al., 2000) and an actinic flux spectroradiometer (Shetter and Muller, 1999), respectively. Ozone $\left(\mathrm{O}_{3}\right)$ was measured with a commercial UV photometric $\mathrm{O}_{3}$ analyzer (TECO, Model 49C). Although no data is presented, ammonia $\left(\mathrm{NH}_{3}(\mathrm{~g})\right)$ was also measured at $\mathrm{T} 1$ and was generally found to be plentiful, consistent with an observed neutral aerosol indicated by the simultaneous presence of significant $\mathrm{SO}_{4}^{2-}$ and $\mathrm{NO}_{3}^{-}$concentrations (Fountoukis and Nenes, 2007). Data from the National Science Foundation (NSF) C-130 aircraft also involved in this study are used in the following analysis to assess the impact of dilution due to boundary layer expansion. This includes PILS-instrumentation for measurements of inorganic ions and WSOC using methods similar to the $\mathrm{T} 1$ site, but modified for aircraft operation (Sullivan et al., 2006; Peltier et al., 2008). In contrast to the T1 surface that involved aerosol composition measurements restricted to $\mathrm{PM}_{2.5}$, the aircraft measured $\mathrm{PM}_{1.0}$. Nitric acid $\left(\mathrm{HNO}_{3}(\mathrm{~g})\right)$ was also measured from the NSF C-130 during this mission by chemical ionization mass spectrometry (Crounse et al., 2006).

The ISORROPIA-II (Nenes et al., 1998; Fountoukis and Nenes, 2007) thermodynamic equilibrium model was used to simulate the thermodynamic partitioning of $\mathrm{NO}_{3}^{-}$. The model uses inputs of ambient temperature, relative humidity, and total concentrations (gas + particle) of inorganic species to predict the equilibrium state of each species along with the aerosol water concentration. Application of the model in Mexico City during the MILAGRO study produced predictions that agreed with measured concentrations within $20 \%$ (Fountoukis et al., 2007).

A box model was constructed to investigate the processes affecting WSOC and $\mathrm{NO}_{3}^{-}$concentrations. From Seinfeld and Pandis (1998), the governing equation for an Eulerian box model with a well-mixed and expanding boundary layer is

$\frac{d c_{i}}{d t}=\frac{1}{H(t)} Q_{i}+R_{i}-\frac{1}{H(t)} S_{i}+\frac{u}{\Delta x}\left(c_{i}^{0}-c_{i}\right)+\frac{1}{H(t)} \frac{d H}{d t}\left(c_{i}^{a}-c_{i}\right)$

where $c_{i}$ is the species $i$ concentration, $c_{i}^{0}$ is the species $i$ background concentration, $c_{i}^{a}$ is the species $i$ concentration aloft, $Q_{i}$ is the emission rate, $R_{i}$ is the chemical production rate, $S_{i}$ is the loss rate, $u$ is the wind speed (with constant $\Delta x$ direction), and $H(t)$ is the boundary layer (BL) height. Direct measurements of BL height data were taken from Shaw et al. (2007). Though BL height data were not available on $3 / 29$, consistencies in meteorological parameters and pollutant profiles (Fig. 1) suggest that the BL growth on 3/29 was similar to $3 / 27$ and $3 / 28$. A conservative tracer, water vapor, was used to estimate dilution from BL growth on $3 / 29$ by using the aloft water vapor mixing ratio measured by the C130. The mean uncertainty in the box model results, due to uncertainty in BL height measurements and in the measured pollutant concentrations, was estimated to be $\sim 35 \%$.

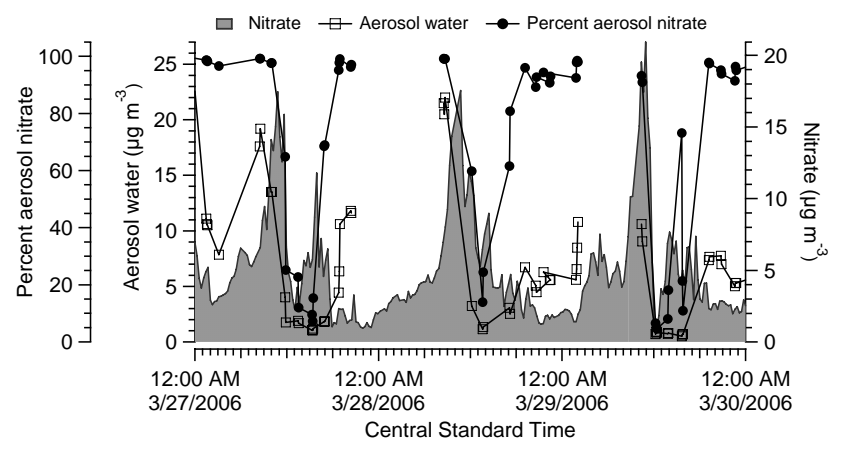

Fig. 2. ISORROPIA-II model output (Percent aerosol nitrate and aerosol water) and measured $\mathrm{NO}_{3}^{-}$for 27-29 March. Based on rising morning temperature and decreasing $\mathrm{RH}$, a sharp decrease in the predicted aerosol water concentration was followed by a rapid equilibrium shift in $\mathrm{NO}_{3}^{-}$from the aerosol to the gas phase. This equilibrium shift produced $\sim 40 \%$ of the observed nitrate concentration decrease.

\section{Results and discussion}

\section{1 $\mathrm{NH}_{4} \mathrm{NO}_{3}$ formation}

$\mathrm{NH}_{4}^{+}$and $\mathrm{NO}_{3}^{-}$were highly correlated $\left(R^{2}=0.82\right)$ during the three days investigated and dominated the inorganic $\mathrm{PM}_{2.5}$ fraction, accounting for an average of $57 \%$ of measured inorganic mass (sum of chloride, nitrite, nitrate, sulfate, sodium, ammonium, calcium, and magnesium). Concentrations of both species increased rapidly with increasing solar radiation starting at approximately 07:30 (Central Standard Time, CST, UTC -6 h) (Fig. 1), suggesting photochemical aerosol formation. The $\mathrm{NO}_{3}^{-}$concentration reached its daily maximum near 11:00 of $18.6 \mu \mathrm{g} \mathrm{m}^{-3}$, an increase of $13.9 \mu \mathrm{g} \mathrm{m}^{-3}$ over pre-sunrise concentrations. The box model was applied to investigate the contribution of secondary nitrate formation to the observed increase. The model was run for the hours 09:00 to 11:00, when BL data were available, and the results likely apply to the early morning hours as well. For the purpose of modeling $\mathrm{NO}_{3}^{-}$in the morning at $\mathrm{T} 1$, a number of assumptions were made to simplify the model. The removal rate, $S_{i}$, was neglected because the dry deposition velocity for $0.1-2.5 \mu \mathrm{m}$ particles $\left(0.01-0.2 \mathrm{~cm} \mathrm{~s}^{-1}\right.$ (Seinfeld and Pandis, 1998)) is not important on the timescale of several hours. Wind speeds, which generally ranged from $1-2 \mathrm{~m} \mathrm{~s}^{-1}$ during the period of interest (Fig. 1), were too low to make advection an important process on the timescale of several hours, either. Each day before 11:00, ISORROPIA-II predicted that greater than $90 \%$ of total nitrate $\left(\mathrm{NO}_{3}^{-}+\mathrm{HNO}_{3}(\mathrm{~g})\right)$ partitioned into the particle phase (Fig. 2) due to thermodynamic conditions that favored the condensed phase, including low $\mathrm{T}$, high $\mathrm{RH}$, and excess ammonia gas $\left(\mathrm{NH}_{3}\right.$ ) (Fountoukis et al., 2007). Thus all predicted $\mathrm{HNO}_{3}(\mathrm{~g})$ produced was assumed to contribute to the observed aerosol nitrate loading. The $\mathrm{HNO}_{3}$ (g) formation rate $\left(\mu \mathrm{g} \mathrm{m}^{-3} \mathrm{hr}^{-1}\right), R_{i}$, was 
Table 1. Average box model predictions for the effects of secondary formation and entrainment on $\mathrm{NO}_{3}^{-}$and $\mathrm{WSOC}$ increases, and the effects of dilution and evaporation on $\mathrm{NO}_{3}^{-}$and WSOC losses. The three WSOC columns represent aloft WSOC concentrations of 0 , 0.7, and $1.4 \mu \mathrm{g} \mathrm{C} \mathrm{m}^{-3}$, respectively (denoted in parentheses).

\begin{tabular}{|c|c|c|c|c|}
\hline & Nitrate $^{\mathrm{a}}$ & $\operatorname{WSOC}(0)^{\mathrm{b}}$ & WSOC $(0.7)^{b}$ & WSOC $(1.4)^{b}$ \\
\hline AM concentration increase & 13.9 & 1.9 & 1.9 & 1.9 \\
\hline AM aloft concentration & 6.4 & 0 & 0.7 & 1.4 \\
\hline $\mathrm{AM} \%$ increase from entrainment & $23 \%$ & $0 \%$ & $15 \%$ & $36 \%$ \\
\hline AM $\%$ increase from secondary formation & $77 \%$ & $100 \%$ & $85 \%$ & $64 \%$ \\
\hline Peak concentration & 18.6 & 4.8 & 4.8 & 4.8 \\
\hline Noon Observed loss & 15.1 & 2.68 & 2.68 & 2.68 \\
\hline Noon Dilution loss & 9.1 & 2.34 & 1.99 & 1.65 \\
\hline Noon Volatility loss & 6.0 & 0.34 & 0.69 & 1.03 \\
\hline Noon Volatility loss (\% of total loss) & $40 \%$ & $13 \%$ & $26 \%$ & $38 \%$ \\
\hline Noon Volatility loss (\% of AM increase) & $43 \%$ & $18 \%$ & $36 \%$ & $54 \%$ \\
\hline Noon Volatility loss (\% of peak concentration) & $32 \%$ & $7 \%$ & $14 \%$ & $21 \%$ \\
\hline
\end{tabular}

a concentrations in units of $\mu \mathrm{g} \mathrm{m}^{-3}$

$\mathrm{b}$ concentrations in units of $\mu \mathrm{g} \mathrm{C} \mathrm{m}^{-3}$

calculated as $k *\left[\mathrm{NO}_{2}\right] *[\mathrm{OH}]$, where $k$ is the temperaturedependent kinetic rate constant (Sander et al., 2006), $\mathrm{NO}_{2}$ was calculated from observations of $\mathrm{NO}, \mathrm{O}_{3}$, J values, and $\mathrm{RO}_{2}$ assuming photochemical steady state, and $\mathrm{OH}$ was measured. After incorporating the stated assumptions, the simplified form of the model was

$$
\frac{d c_{i}}{d t}=k\left[\mathrm{NO}_{2}\right][\mathrm{OH}]+\frac{1}{H(t)} \frac{d H}{d t}\left(c_{i}^{a}-c_{i}\right)
$$

The model was then solved for $c_{i}^{a}$, the $\mathrm{NO}_{3}^{-}$concentration in air entrained by the expanding BL and the two right hand terms (photochemical production and dilution) were compared. From 09:00-11:00, the BL expanded from, on average, $510 \mathrm{~m}$ to $1100 \mathrm{~m}$. Model results indicate that approximately $75-80 \%$ of the observed nitrate concentration increase was due to secondary photochemical production (Table 1). By comparison to the observed $\mathrm{NO}_{3}^{-}$concentration, mass conservation indicated that the average $\mathrm{NO}_{3}^{-}$concentration in the entrained layer was $6.4 \mu \mathrm{g} \mathrm{m}^{-3}$ and was responsible for approximately $20-25 \%$ of the observed $\mathrm{NO}_{3}^{-}$ increase.

On $3 / 29$, the C-130 flew in the vicinity $(0-90 \mathrm{~km})$ of $\mathrm{T} 1$ between the hours of 11:00-15:00 CST, including a pass directly over the site at 14:00. During this time, the plane flew primarily within the BL, but did sample out of the BL on several occasions. Sampling in versus out of the BL was determined by water vapor concentration, which showed rapid changes with minor altitude changes when the threshold was crossed. During this time, the mean concentration of total nitrate $\left(\mathrm{NO}_{3}^{-}+\mathrm{HNO}_{3}(\mathrm{~g})\right)$ in the $1 \mathrm{~km}$ layer above the $\mathrm{BL}$ was $1.5 \pm 1.3$ (one standard deviation) $\mu \mathrm{g} \mathrm{m}^{-3}$. Assuming these aloft measurements are representative of what was entrained into the BL during the morning nitrate production, they sug- gest that the predictions of nitrate production were low, and that the contribution from photochemical production to the $\mathrm{NO}_{3}^{-}$increase was perhaps as high as $90-95 \%$.

Overall, the present results qualitatively agree with previous studies (Salcedo et al., 2006; Volkamer et al., 2006) in the MCMA, which observed a similar morning production of $\mathrm{HNO}_{3}(\mathrm{~g})$ immediately followed by $\mathrm{NH}_{4} \mathrm{NO}_{3}$ formation. This morning photochemical $\mathrm{NO}_{3}^{-}$production appears to be a common phenomenon in the MCMA.

\subsection{Nitrate loss}

The $\mathrm{NO}_{3}^{-}$peak was short lived, as concentrations began to drop precipitously at approximately 11:00 (Fig. 1). Over the period between $\sim 11: 00$ and $\sim 12: 45$, the $\mathrm{NO}_{3}^{-}$concentration decreased by an average of $15.1 \mu \mathrm{g} \mathrm{m}^{-3}$, an $81 \%$ drop from the peak concentration. This decrease occurred while the $\mathrm{HNO}_{3}(\mathrm{~g})$ production rate $\left(k[\mathrm{OH}]\left[\mathrm{NO}_{2}\right]\right)$ remained relatively high. Causes of this concentration decrease following the late morning maximum are hypothesized as a combination of boundary layer dilution and chemical processes (i.e., particle evaporation). Precipitation data showed that wet deposition was not important on any of the days in question. We first investigate the role of chemical processes, followed by the effects of meteorological processes on ambient concentrations.

The effect of a thermodynamic phase shift on $\mathrm{NO}_{3}^{-}$was examined with ISORROPIA-II and model results are shown in Fig. 2. Based on rising ambient temperature and decreasing relative humidity, the model predicted a rapid phase shift of $\mathrm{NO}_{3}^{-}$to $\mathrm{HNO}_{3}(\mathrm{~g}) . \mathrm{NH}_{4} \mathrm{NO}_{3}$ is semi-volatile and is sensitive to changes in RH and temperature (both of which directly impact aerosol water content), with higher temperature 
(lower RH) favoring the gas phase and lower temperature (higher $\mathrm{RH}$ ) favoring the particle phase. (Recall that $\mathrm{NH}_{3}$ (g) was ubiquitous at this site). It is notable that the predicted equilibrium shift coincided with the large observed decrease in $\mathrm{NO}_{3}^{-}$concentration (Fig. 2). ISORROPIA-II predicted an average morning aerosol water concentration maximum of $15.4 \mu \mathrm{g} \mathrm{m}^{-3}$, followed by a rapid concentration decrease to $1.2 \mu \mathrm{g} \mathrm{m}^{-3}$ that preceded the $\mathrm{NO}_{3}^{-}$concentration drop by approximately $1 \mathrm{~h}$. Given additional time for aerosol evaporation following the water loss, the timescale of this observed delay is consistent with the analysis of Fountoukis et al. (2007). The observational data and model results agree well and suggest that, despite continued production of $\mathrm{HNO}_{3}$ (g) and available $\mathrm{NH}_{3}(\mathrm{~g})$, changing ambient conditions produced a rapid shift in the equilibrium of the system towards the gas phase and were responsible for some fraction of the observed $\mathrm{NO}_{3}^{-}$loss.

Dilution must also be considered because the boundary layer underwent rapid expansion during the nitrate decrease. With two assumptions, the box model was also used to assess the relative contribution of $\mathrm{BL}$ dilution on the $\mathrm{NO}_{3}^{-}$concentration decrease. The average $\mathrm{NO}_{3}^{-}$loss, if dilution was the sole factor contributing to its decrease, was $9.1 \mu \mathrm{g} \mathrm{m}^{-3}$ (Table 1). Because of the thermodynamic shift predicted by ISORROPIA-II, the difference between the observed $\mathrm{NO}_{3}^{-}$decrease $\left(15.1 \mu \mathrm{g} \mathrm{m}^{-3}\right)$ and that predicted by dilution $\left(9.1 \mu \mathrm{g} \mathrm{m}^{-3}\right)$ was attributed to volatility. Thus $6 \mu \mathrm{g} \mathrm{m}^{-3}$, or $40 \%$, of the concentration decrease was from particle evaporation while $60 \%$ was due to dilution. This analysis incorporated two major assumptions that set the evaporation estimate as a lower bound. First, the effect of continued $\mathrm{HNO}_{3}(\mathrm{~g})$ production and its conversion to $\mathrm{NH}_{4} \mathrm{NO}_{3}$ throughout this time was neglected. The second assumption was that the $\mathrm{NO}_{3}^{-}$concentration aloft was neglected. Due to ISORROPIA-II predictions, we assume that any $\mathrm{NO}_{3}^{-}$entrained during this time evaporated and any $\mathrm{HNO}_{3}(\mathrm{~g})$ formed remained predominantly in the gas phase. Any $\mathrm{NO}_{3}^{-}$in the entrained air that did not evaporate or photochemical $\mathrm{NO}_{3}^{-}$ formation during this time would translate to volatility losses greater than the $40 \%$ estimated by the above method, thus our estimation method is likely conservative.

It should also be noted that shortly after the concentration decrease, the $\mathrm{NO}_{3}^{-}$(and WSOC) concentration increased rapidly (Fig. 1). This smaller mid-afternoon increase is not investigated in this paper.

\subsection{Photochemical WSOC production}

For the three-day analysis period, the WSOC concentration increased an average of $1.9 \mu \mathrm{g}$ Carbon $\mathrm{m}^{-3}\left(\mu \mathrm{g} \mathrm{C} \mathrm{m}^{-3}\right)$ over the three-hour period from 08:00 to 11:00 each day and had an average peak of $4.8 \mu \mathrm{g} \mathrm{C} \mathrm{m}^{-3}$ before noon (Fig. 1). The box model was also run to assess the contribution of SOA formation to the WSOC concentration increase, though the

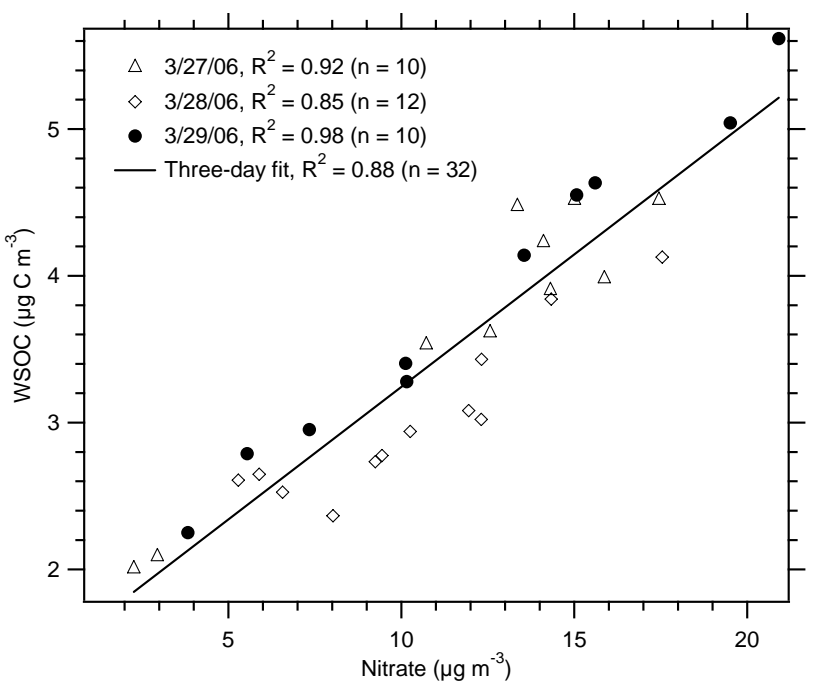

Fig. 3. Correlations between $\mathrm{NO}_{3}^{-}$and WSOC during the hours of 08:00-12:45 on the three days of interest. The high correlation suggests similar sources and atmospheric processing of the two species.

methodology was different from that used in the $\mathrm{NO}_{3}^{-}$analysis. In this case, since the WSOC (or SOA) chemical production rate $\left(R_{i}\right)$ is unknown, the model used measured concentrations of WSOC aloft and conservation of mass principles to predict secondary formation. The C-130 measurements on 3/29 indicate that the average WSOC concentration in the $1 \mathrm{~km}$ layer directly above the BL was $0.7 \pm 0.7$ (one standard deviation) $\mu \mathrm{g} \mathrm{C} \mathrm{m}^{-3}$. Using the mean of measured aloft concentrations, the model predicted that $\sim 15 \%$ of the concentration increase was due to entrainment and roughly $\sim 85 \%$ was due to SOA formation (Table 1). Similar rapid morning photochemical production of SOA has been observed previously in the MCMA (Salcedo et al., 2006; Volkamer et al., 2006). Because of the relatively large variability in the aloft WSOC concentrations, Table 1 also presents box model results for aloft WSOC concentrations of 0 and $1.4 \mu \mathrm{g} \mathrm{C} \mathrm{m}^{-3}$ (mean \pm one standard deviation). The results indicate that the contribution from photochemical production to the morning concentration increase was in the range of $65-100 \%$.

The WSOC increase from SOA formation was approximately the same relative enhancement $\mathrm{NO}_{3}^{-}$experienced due to secondary photochemical formation (Table 1). For the entire three-day period, WSOC and $\mathrm{NO}_{3}^{-}$were highly correlated $\left(R^{2}=0.80\right)$, however between $08: 00$ and $12: 45$, the correlation $\left(R^{2}=0.88\right)$ was even stronger (Fig. 3$)$. The high correlations suggest that during these periods the sources and atmospheric processes affecting both species were likely very similar. That is, the similar contributions of entrainment and secondary formation made to $\mathrm{NO}_{3}^{-}$and WSOC concentrations help explain the high correlations. Because the contributions from biomass burning were presumed to be small, it is likely that anthropogenic sources were responsible for the majority of the observed $\mathrm{NO}_{3}^{-}$and WSOC. Furthermore, the 
strong WSOC- $\mathrm{NO}_{3}^{-}$correlation is also suggestive that $\mathrm{OH}$ was the primary oxidation pathway in the observed SOA formation.

\subsection{WSOC loss}

Similar to $\mathrm{NO}_{3}^{-}$, the WSOC concentration experienced a daily decrease shortly after the morning maximum. Between $\sim 11: 00$ and $\sim 12: 45$, the WSOC concentration decreased an average of $2.68 \mu \mathrm{g} \mathrm{C} \mathrm{m}^{-3}$, a $56 \%$ decrease from the peak concentration. Using the average aloft WSOC concentration $\left(0.7 \mu \mathrm{g} \mathrm{C} \mathrm{m}^{-3}\right)$ measured on $3 / 29$, the box model was used to investigate WSOC losses between 11:00 and $12: 45$ as well. During this time, average BL expansion was from $1100 \mathrm{~m}$ to $2040 \mathrm{~m}$ and the average WSOC loss due to dilution was $1.99 \mu \mathrm{g} \mathrm{C} \mathrm{m}^{-3}$. WSOC loss due to evaporation was $0.69 \mu \mathrm{g} \mathrm{C} \mathrm{m}^{-3}$, on average, and accounted for $\sim 25 \%$ of the observed concentration decrease. This decrease was substantial, as $\sim 15 \%$ of WSOC at its peak concentration $\left(4.8 \mu \mathrm{g} \mathrm{C} \mathrm{m}^{-3}\right)$ and $\sim 35 \%$ of the newly formed WSOC $\left(1.9 \mu \mathrm{g} \mathrm{C} \mathrm{m}^{-3}\right)$ likely volatilized (Table 1$)$. Similar to the $\mathrm{NO}_{3}^{-}$analysis, the production of WSOC during the concentration decrease was ignored. Any production during this time would yield an under-prediction of the evaporation contribution to observed WSOC losses.

Because of the high relative variation in aloft WSOC concentrations, the box model was also run with alternate inputs ( 0 and $1.4 \mu \mathrm{g} \mathrm{C} \mathrm{m}^{-3}$ aloft WSOC concentrations), and the results provide an estimate of the range of WSOC losses due to evaporation (Table 1). For an aloft WSOC concentration equal to zero, the average evaporation loss was only $0.34 \mu \mathrm{g} \mathrm{C} \mathrm{m}^{-3}$. This represents less than $20 \%$ of the newly formed WSOC, and less than $10 \%$ of the peak WSOC. For an aloft WSOC concentration $=1.4 \mu \mathrm{g} \mathrm{C} \mathrm{m}^{-3}$, the average evaporation loss was $1.03 \mu \mathrm{g} \mathrm{C} \mathrm{m}^{-3}$. This represents greater than $50 \%$ of the newly formed WSOC, and greater than $20 \%$ of the total WSOC at its peak.

These findings provide insight into the semi-volatile nature of ambient SOA, an area in which knowledge is currently limited. Specifically, the results suggest that, on average, a meaningful fraction of the observed newly formed (1-3h old) WSOC mass possessed similar semi-volatile properties to $\mathrm{NH}_{4} \mathrm{NO}_{3}$ at the $\mathrm{T}$ and $\mathrm{RH}$ recorded here (Fig. 1), though $\mathrm{NO}_{3}^{-}$evaporation losses by this analysis were about $50 \%$ greater (evaporation caused $40 \%$ of total $\mathrm{NO}_{3}^{-}$loss, $26 \%$ of total WSOC loss) than those of WSOC (Table 1). This implies that, similar to $\mathrm{NH}_{4} \mathrm{NO}_{3}$, the loss of aerosol water affected WSOC as well. In contrast, a study by Loeffler et al. (2006) found that when aqueous particles containing glyoxal and methylglyoxal were evaporated, there was minimal loss of particulate organic mass due to oligomer formation. However, other studies report on a fairly volatile SOA or total organic aerosol. Grieshop et al. (2007) found the partitioning of fresh biogenic SOA generated in a smog chamber to be reversible when subjected to isothermal dilution, and Wil- son et al. (2006) found the semi-volatile character of a large fraction of the organic aerosol (primary plus secondary) to be similar to that of $\mathrm{NH}_{4} \mathrm{NO}_{3}$ in filter sampling performed in both urban and rural locations.

Finally, additional airborne measurements made over the sampling sites during MILAGRO have been used to investigate the production of SOA and $\mathrm{NO}_{3}^{-}$by changes in concentrations with respect to $\mathrm{CO}$ as plumes were advected away from the urban region (Kleinman et al., 2008). They found that $\mathrm{NO}_{3}^{-}$and SOA production differed; SOA was still produced relative to $\mathrm{CO}$ when net $\mathrm{NO}_{3}^{-}$production had apparently stopped. They concluded that this was due to the more semi-volatile nature of $\mathrm{NO}_{3}^{-}$, compared to SOA.

\section{Model assumptions}

Here we attempt to address and justify the major assumptions used for the modeling analyses. First, in the model assessment of $\mathrm{NO}_{3}^{-}$formation, $\mathrm{NO}_{2}$ was calculated from measurements of $\mathrm{NO}, \mathrm{O}_{3}, \mathrm{RO}_{2}$ and $\mathrm{J}$ values assuming photochemical steady state. This assumption will impart added uncertainty to the estimated $\mathrm{HNO}_{3}(\mathrm{~g})$ formation rates, and will add uncertainty to the predictions of photochemical/entrainment contributions to concentrations. The model results predicted a higher aloft nitrate concentration $\left(6.4 \mu \mathrm{g} \mathrm{m}^{-3}\right)$ than that observed $\left(1.5 \mu \mathrm{g} \mathrm{m}^{-3}\right)$, something which may be due to an under-prediction of $\mathrm{HNO}_{3}(\mathrm{~g})$ formation rates. If $\mathrm{HNO}_{3}(\mathrm{~g})$ formation rates were under predicted by this degree, the contribution of photochemical production to the morning $\mathrm{NO}_{3}^{-}$ increase would be greater (90-95\%) than predicted levels (77\%). Overall, though, both results indicate that the major factor affecting morning $\mathrm{NO}_{3}^{-}$concentrations was its production through photochemical processes.

A second major assumption, necessitated by unavailable BL height, was the use of water vapor as a conservative tracer to estimate BL dilution on 3/29. Consistencies in meteorological parameters and pollutant concentrations and profiles (Fig. 1) suggest that the BL behaved similarly on $3 / 27,3 / 28$, and $3 / 29$. Using $4480 \mathrm{ppm}$ as the aloft mixing ratio based on the $\mathrm{C}-130$ observations made on $3 / 29$, the water vapor tracer method predicted dilution values on $3 / 27$ and $3 / 28$ that were within $20 \%$ of those observed. This suggests that the use of water vapor to estimate dilution on 3/29 was reasonable.

Finally, the modeling of WSOC was based on aircraft measurements above the BL to determine an aloft WSOC concentration. The major assumptions in this analysis were 1) that the aircraft measurements were representative of the air entrained during BL expansion, 2) that measurements on $3 / 29$ were representative of conditions on $3 / 27$ and $3 / 28$, and 3 ) that the WSOC in the entrained air was not volatile. First, the aloft water vapor mixing ratio used to estimate dilution on $3 / 29$ came from measurements on the same flight, and during the same times that the aloft WSOC determinations were made. As discussed, using these water vapor values, the dilution on $3 / 27$ and $3 / 28$ were predicted within $20 \%$ of observed 
values. This suggests that the aircraft measurements above the $\mathrm{BL}$ on $3 / 29$ were representative of air that was entrained due to BL expansion on all three days. The aircraft measurements were also in fair agreement with the surface measurements during BL sampling. For approximately 40 minutes in the mid-afternoon (13:46-14:23, CST), the C-130 made measurements within the $\mathrm{BL}$ that included passage over $\mathrm{T} 1$. During this time, the ratio of mean $\mathrm{NO}_{3}^{-}, \mathrm{SO}_{4}^{2-}$, and WSOC concentrations measured via PILS on the C-130 to mean concentrations on the ground were $0.52,1.01$, and 0.79 , respectively. Additionally, as has been stated previously, the meteorology and pollutants (magnitude of concentrations and diurnal patterns) were remarkably similar on all three days (Fig. 1). Because of this, the concentrations of species mixing down with BL expansion were likely similar on each day.

The properties of WSOC in air entrained with BL expansion also add uncertainty to the model results. Kalberer et al. (2004) found that the volatility of chamber-generated SOA decreased significantly with time. It is likely that WSOC above the BL was aged, and thus was less volatile than the WSOC formed in the morning at the surface. If the entrained WSOC was completely volatile (or if the WSOC concentration in the entraining air was zero), then the box model results indicate that WSOC losses due to evaporation $\left(0.34 \mu \mathrm{g} \mathrm{C} \mathrm{m}^{-3}\right.$, average) would be roughly half $\left(0.69 \mu \mathrm{g} \mathrm{C} \mathrm{m}^{-3}\right.$, average) of that predicted with aloft (and non-volatile) WSOC concentration of $0.7 \mu \mathrm{g} \mathrm{C} \mathrm{m}^{-3}$. This implies a baseline case of only $\sim 10 \%$ loss due to volatility (or only $\sim 18 \%$ of the morning WSOC concentration increase), however the likelihood that either the WSOC concentration aloft was zero or the WSOC aloft was $100 \%$ volatile are both very low.

\section{Conclusions}

In 2006, gas phase and $\mathrm{PM}_{2.5}$ aerosol measurements were made in the Mexico City Metropolitan Area as part of the MILAGRO field study. For three days (3/27-3/29), $\mathrm{NO}_{3}^{-}$and WSOC were highly correlated $\left(R^{2}=0.88\right)$ during the morning and early afternoon hours when concentrations of these species grew quickly and then fell even more rapidly. Box model results indicate that the $\mathrm{NO}_{3}^{-}$and WSOC concentration increases were caused by secondary production $(\sim 75-$ $85 \%)$ and the entrainment of air in an expanding boundary layer $(\sim 15-25 \%)$. Following the rapid increase in concentration, the model predicts that at least $40 \%$, but likely more, of the $\mathrm{NO}_{3}^{-}$concentration decrease was due to particle evaporation. This matched well with thermodynamic predictions (results from ISORROPIA-II), which indicated a rapid shift in the $\mathrm{NO}_{3}^{-}$equilibrium from almost completely in the particle phase during the observed morning increase to the gas phase during the subsequent period of observed $\mathrm{NO}_{3}^{-}$drop. Similar to $\mathrm{NO}_{3}^{-}$, volatilization also contributed to the WSOC loss ( $\sim 25 \%$ of total WSOC loss), but to a lesser extent. The high correlation and similar model results indicate that the two likely share common sources and that the fresh SOA observed was anthropogenic, with $\mathrm{OH}$ reaction being the initiator. The results provide novel insight into the semi-volatile nature of fresh, anthropogenic, ground-level SOA, however their translation to other environments requires further examination.

Acknowledgements. This research and the measurements at the Mexico City T1 site were funded by the National Science Foundation, through grant ATM 0513035. Aircraft measurements were funded through the National Aeronautic and Space Administration through grant NNG06GA68G. A. Nenes acknowledges the support of the National Oceanic and Atmospheric Administration, grant NMRAC000-5-04017; and the US Environmental Protection Agency, grant X83234201. The authors would also like to thank Will Shaw for providing boundary layer data, and Paul Wennberg (supported by NASA grant NNG06GB32G) for nitric acid data.

Edited by: S. Madronich

\section{References}

An, W. J., Pathak, R. K., Lee, B. H., and Pandis, S. N.: Aerosol volatility measurement using an improved thermodenuder: Application to secondary organic aerosol, J. Aerosol Sci., 38(3), 305-314, 2007.

Crounse, J. D., McKinney, K. A., Kwan, A. J., and Wennberg, P. O.: Measurement of Gas-Phase Hydroperoxides by Chemical Ionization Mass Spectrometry, Anal. Chem., 78, 6726-6732, 2006.

de Gouw, J. A., Warneke, C., Stohl, A., Wollny, A. G., Brock, C. A., Cooper, O. R., Holloway, J. S., Trainer, M., Fehsenfeld, F. C., Atlas, E. L., Donnelly, S. G., Stroud, V., and Lueb, A.: Volatile organic compounds composition of merged and aged forest fire plumes from Alaska and western Canada, J. Geophys. Res., 111(D10), 20, D10303, doi:10.1029/2005JD006175, 2006.

Eatough, D. J., Long, R. W., Modey, W. K., and Eatough, N. L.: Semi-volatile secondary organic aerosol in urban atmospheres: meeting a measurement challenge, Atmos. Environ., 37(9-10), 1277-1292, 2003.

Fountoukis, C. and Nenes, A.: ISORROPIA II: A Computationally Efficient Aerosol Thermodynamic Equilibrium Model for $\mathrm{K}^{+}$, $\mathrm{Ca}^{2+}, \mathrm{Mg}^{2+}, \mathrm{NH}_{4}^{+}, \mathrm{Na}^{+}, \mathrm{SO}_{4}^{2-}, \mathrm{NO}_{3}^{-}, \mathrm{Cl}^{-}, \mathrm{H}_{2} \mathrm{O}$ Aerosols, Atmos. Chem. Phys., 7, 4639-4659, 2007, http://www.atmos-chem-phys.net/7/4639/2007/.

Fountoukis, C., Nenes, A., Sullivan, A., Weber, R., VanReken, T., Fischer, M., Matías, E., Moya, M., Farmer, D., and Cohen, R. C.: Thermodynamic characterization of Mexico City aerosol during MILAGRO 2006, Atmos. Chem. Phys. Discuss., 7, 9203-9233, 2007, http://www.atmos-chem-phys-discuss.net/7/9203/2007/.

Grieshop, A. P., Donahue, N. M., and Robinson, A. L.: Is the gas-particle partitioning in alpha-pinene secondary organic aerosol reversible?, Geophys. Res. Lett., 34, L14810, doi:10.1029/2007GL029987, 2007.

Henze, D. K. and Seinfeld, J. H.: Global secondary organic aerosol from isoprene oxidation, Geophys. Res. Lett., 33, L09812, doi:10.1029/2006GL025976, 2006. 
Kalberer, M., Paulsen, D., Sax, M., Steinbacher, M., Dommen, J., Prevot, A. S. H., Fisseha, R., Weingartner, E., Frankevich, V., Zenobi, R., and Baltensperger, U.: Identification of polymers as major components of atmospheric organic aerosols, Science, 303(5664), 1659-1662, 2004.

Kanakidou, M., Seinfeld, J. H., Pandis, S. N., Barnes, I., Dentener, F. J., Facchini, M. C., Van Dingenen, R., Ervens, B., Nenes, A., Nielsen, C. J., Swietlicki, E., Putaud, J. P., Balkanski, Y., Fuzzi, S., Horth, J., Moortgat, G. K., Winterhalter, R., Myhre, C. E. L., Tsigaridis, K., Vignati, E., Stephanou, E. G., and Wilson, J.: Organic aerosol and global climate modelling: a review, Atmos. Chem. Phys., 5, 1053-1123, 2005,

http://www.atmos-chem-phys.net/5/1053/2005/.

Kleinman, L. I., Springston, S. R., Daum, P. H., Lee, Y.-N., Nunnermacker, L. J., Senum, G. I., Wang, J., Weinstein-Lloyd, J., Alexander, M. L., Hubbe, J., Ortega, J., Canagaratna, M. R., and Jayne, J.: The time evolution of aerosol composition over the Mexico City plateau, Atmos. Chem. Phys., 8, 1559-1575, 2008, http://www.atmos-chem-phys.net/8/1559/2008/.

Kondo, Y., Miyazaki, Y., Takegawa, N., Miyakawa, T., Weber, R. J., Jimenez, J. L., Zhang, Q., and Worsnop, D. R.: Oxygenated and water-soluble organic aerosols in Tokyo, J. Geophys. Res., 112(D1), 11, D01203, doi:10.1029/2006JD007056, 2007.

Loeffler, K. W., Koehler, C. A., Paul, N. M., and De Haan, D. O.: Oligomer formation in evaporating aqueous glyoxal and methyl glyoxal solutions, Environ. Sci. Technol., 40(20), 6318-6323, 2006.

Modey, W. K. and D. J. Eatough, Twenty four-hour PC-BOSS airmonitoring results from the NETL fine-particulate sampling site in Pittsburgh, Pennsylvania: an annual perspective, Aerosol Sci. Technol., 38(3), 194-204, 2004.

Nenes, A., Pandis, S. N., and Pilinis, C.: ISORROPIA: A new thermodynamic equilibrium model for multiphase multicomponent inorganic aerosols, Aquat. Geochem., 4(1), 123-152, 1998.

Offenberg, J. H., Kleindienst, T. E., Jaoui, M., Lewandowski, M., and Edney, E. O.: Thermal properties of secondary organic aerosols, Geophys. Res. Lett., 33, L03816, doi:10.1029/2005GL024623, 2006.

Orsini, D. A., Ma, Y. L., Sullivan, A., Sierau, B., Baumann, K., and Weber, R. J.: Refinements to the particle-into-liquid sampler (PILS) for ground and airborne measurements of water soluble aerosol composition, Atmos. Environ., 37(9-10), 1243-1259, 2003.

Peltier, R. E., Hecobian, A. H., Weber, R. J., Stohl, A., Atlas, E. L., Riemer, D. D., Blake, D. R., Apel, E., Campos, T., and Karl, T.: Investigating the Sources and Atmospheric Processing of Fine Particles from Asia and North America Measured During INTEX B, Atmos. Chem. Phys., 8, 1835-1853, 2008,

http://www.atmos-chem-phys.net/8/1835/2008/.

Ryerson, T. B., Williams, E. J., and Fehsenfeld, F. C.: An efficient photolysis system for fast-response $\mathrm{NO}_{2}$ measurements, J. Geophys. Res., 105(D21), 26447-26462, doi:10.1029/2000JD900389, 2000.

Sander, S. P., Friedl, R. R., Golden, D. M., Kurylo, M. J., Moortgat, G. K., Keller-Rudek, H., Wine, P. H., Ravishankara, A. R., Kolb, C. E., Molina, M. J., Finlayson-Pitts, B. J., Huie, R. E., and Orkin, V. L.: Chemical kinetics and photochemical data for use in atmospheric studies, Evaluation Number 15, JPL Publication 06-2, Jet Propulsion Laboratory, Pasadena, 2006.
Salcedo, D., Onasch, T. B., Dzepina, K., Canagaratna, M. R., Zhang, Q., Huffman, J. A., DeCarlo, P. F., Jayne, J. T., Mortimer, P., Worsnop, D. R., Kolb, C. E., Johnson, K. S., Zuberi, B., Marr, L. C., Volkamer, R., Molina, L. T., Molina, M. J., Cardenas, B., Bernabe, R. M., Marquez, C., Gaffney, J. S., Marley, N. A., Laskin, A., Shutthanandan, V., Xie, Y., Brune, W., Lesher, R., Shirley, T., and Jimenez, J. L.: Characterization of ambient aerosols in Mexico City during the MCMA-2003 campaign with Aerosol Mass Spectrometry: results from the CENICA Supersite, Atmos. Chem. Phys., 6, 925-946, 2006,

http://www.atmos-chem-phys.net/6/925/2006/.

Seinfeld, J. H. and Pandis, S. N.: Atmospheric Chemistry and Physics, From Air Pollution to Climate Change, John Wiley \& Sons, New York, NY, 1998.

Seinfeld, J. H. and Pankow, J. F.: Organic atmospheric particulate material, Annu. Rev. Phys. Chem., 54, 121-140, 2003.

Shaw, W. J., Pekour, M. S., Coulter, R. L., Martin, T. J., and Walters, J. T.: The daytime mixing layer observed by radiosonde, profiler, and lidar during MILAGRO, Atmos. Chem. Phys. Discuss., 7, 15025-15065, 2007.

Shetter, R. E. and Muller, M.: Photolysis frequency measurements using actinic flux spectroradiometry during the PEM-Tropics mission: Instrumentation description and some results, J. Geophys. Res., 104(D5), 5647-5662, doi:10.1029/98JD01381, 1999.

Sjostedt, S. J., Huey, L. G., Tanner, D. J., Peischl, J., Chen, G., Dibb, J. E., Lefer, B., Hutterli, M. A., Beyersdorf, A. J., Blake, N. J., Blake, D. R., Sueper, D., Ryerson, T., Burkhart, J., and Stohl, A.: Observations of hydroxyl and the sum of peroxy radical at Summit, Greenland during summer 2003, Atmos. Environ., 41, 5122-5137, 2007.

Stone, E. A., Snyder, D. C., Sheesley, R. J., Sullivan, A. P., Weber, R. J., and Schauer, J. J.: Source apportionment of fine organic aerosol in Mexico City during the MILAGRO Experiment 2006, Atmos. Chem. Phys., 8, 1249-1259, 2008, http://www.atmos-chem-phys.net/8/1249/2008/.

Sullivan, A. P., Weber, R. J., Clements, A. L., Turner, J. R., Bae, M. S., and Schauer, J. J.: A method for on-line measurement of water-soluble organic carbon in ambient aerosol particles: Results from an urban site, Geophys. Res. Lett., 31, L13105, doi:10.1029/2004GL019681, 2004.

Sullivan, A. P., Peltier, R. E., Brock, C. A., de Gouw, J. A., Holloway, J. S., Warneke, C., Wollny, A. G., and Weber, R. J.: Airborne measurements of carbonaceous aerosol soluble in water over northeastern United States: Method development and an investigation into water-soluble organic carbon sources, J. Geophys. Res., 111, D23S46, doi:10.1029/2006JD007072, 2006.

Volkamer, R., Jimenez, J. L., San Martini, F., Dzepina, K., Zhang, Q., Salcedo, D., Molina, L. T., Worsnop, D. R., and Molina, M. J.: Secondary organic aerosol formation from anthropogenic air pollution: Rapid and higher than expected, Geophys. Res. Lett., 33, L17811, doi:10.1029/2006GL026899, 2006.

Wilson, W. E., Grover, B. D., Long, R. W., Eatough, N. L., and Eatough, D. J.: The measurement of fine particulate semivolatile material in urban aerosols, J. Air Waste Manage. Assoc., 56(4), 384-397, 2006.

Yu, J. Z., Yang, H., Zhang, H. Y., and Lau, A. K. H.: Size distributions of water-soluble organic carbon in ambient aerosols and its size-resolved thermal characteristics, Atmos. Environ., 38(7), 1061-1071, 2004. 